sions, too, displayed 'independence and originality' (p. 262). The notion of the conscious selection of 'progressive' features from what was on offer is inadequate to explain the complex interaction of foreign styles and local traditions, but if the reader of this book can detach himself from its ideological framework, he should be able to judge for himself the extent of Byelorussian 'independence and originality' from the many excellent photographs and drawings and the clear, often detailed descriptions which Canturija provides.

As the author states in his preface, the study and evaluation of architectural monuments and their incorporation into new planning projects is of 'extraordinary importance', particularly, one might add, in Byelorussia, where much has been destroyed over the centuries. The bulldozer-happy days of earlier decades appear to have been superseded by a more sensitive approach to reconstruction (see, for example, the 1976 Soviet law 'On the preservation and utilization of monuments of history and culture'), but the definition of a monument. remains crucial. Canturija suggests that his book will help the student 'to assess for himself the value of the surviving architectural heritage' (p. 7). It is to be hoped that it will help to instil respect not only for magnificent palaces, cathedrals and castles but also for the more humble buildings which have shaped the appearance of Byelorussian towns and villages and which Canturija's ideological framework brings to the fore.

\section{Lindsey Hughes}

1. V. A. Canturija, Istorija architektury
Belorussii. Dooktjabr'skij period, Minsk. 1969.

Kupała, Janka. Zbor tvoraŭ. Ed, by V. Barysienka et al. Vols 1-7. 'Navuka i Technika', Minsk, 1972-76. Ill., indices. (Akademija Navuk Biełaruskaj SSR. Instytut Litaratury imia Janki Kupały.)

This is the third edition of Janka Kupała's collected works since his death, the previous two having appeared in 1951-54 and 1962-63. Published under the auspices of the Janka Kupała Institute of Literature of the Byelorussian Academy of Sciences, and prepared by a team of scholars, some of them well known for their studies of Kupała's works, it claims to be, to quote the words from the preface, 'the most complete and scientifically exact edition of the works of the national poet' (Vol. 1, p. 5). The arrangement of the material follows traditional patterns. The first four volumes consist of collections of Kupała's original verse and translations from works of Polish, Russian and Ukrainian authors for the years 1904-1907, 1908-10, 1911-17, and 191842 resp.; in the 5th volume there are his longer poems from various years, such as Kurhan, Bandaroŭna, Mahila Iva, Bieznazoŭnaje and others, as well as longer translations, including The Lay of Igor's Campaign and Taras Sevčenko's Katerina; the 6th volume contains Kupała's plays (Paŭlinka, Raskidanaje hniazdo, Prymaki) and dramatic poems Son na kurhanie, Adviečnaja pieśnia, Na papasie; the 7th - a selection of his essays, newspaper articles and private correspondence, as well as translations of $\mathrm{W}$. Wolski's libretto of S. Moniuszko's opera Halka and E. Żuławski's play Eros $i$ Psyche. All volumes are provided with full critical notes and commentaries, containing textual variants whenever such exist, as well as with useful alphabetical indexes of works contained in a given volume. The general alphabetical index to all volumes, and a detailed chronicle of the poet's life, are to be found in Vol. 7. One of the pleasant features of the whole publication is its attractive exterior appearance which does credit to the taste and ability of the artist responsible for its execution.

Some new material, not found in earlier editions, has been included in the present publication. Thus Vol. 1 contains Kupała's 21 short poems in Polish, written by him in 1906 , but never before published in any book. (The only previous publication is that by A. Barščeŭski in the Navukovy zbornik, Białystok, 1964.) On the whole, however, the editors' claim to the completeness and exactness of the publication is not borne out by the facts. A closer acquaintance with its 
contents reveals several important om:ssions. These may be roughly divided into two groups. The first group consists of Kupała's earlier works, written not later than the early 1920s. Among them there are well known titles such as the play $T u t e j-$ šyja (The Natives vitten in 1922, first published in the journal Potymia in 1924), the long poem $\mathrm{Na} \mathrm{Kućciu} \mathrm{(On}$ Christmas Eve, first published in the newspaper Naša Niva in 1911, and reprinted in the book of collected poems S̆lacham žyćcia in 1913), as well as the poems Caraünik (The Wizard, 1913), Na Dziady (On 'Ancestors' Remembrance Day', 1912), Nad Niomnam (On the Bank of River Nioman, 1913), Pierad budučyniaj (Before the Future, 1922) and several others. What all these works have in common is that the sentiments expressed in them can hardly please, or be approved by, the present-day establishment in Soviet Byelorussia. The second group of omissions comprises works written during the years 1935-42. It was the period which is today euphemistically called 'the personality cult', and $\mathrm{Ku}$ pała, along with other poets in the Soviet Union, was forced to compose hymns in praise of Stalin and his rule. Doubtless, it was the price they had to pay for their survival. It was during that time that Kupała wrote the poems Tabie, pravadyr, maje pieśni $i$ dumy (To you, $O$ Leader, belong my songs and my thoughts, 1936), Ab Stalinie siejbitu (Stalin the Sower, 1937), Ja Stalinu mudramu pieśni śpiavaju (I sing songs in praise of Wise Stalin, 1939) and others. No doubt the powers-that-be today in Soviet Byelorussia prefer not to be reminded of this period, and Kupała himself, if he were alive, would probably not be proud of what he was forced to write. Nevertheless, in a critical edition of his collected works, these poems should be included, perhaps as an appendix, both for the sake of completeness and as a document of those tragic times.

Several other works have been included in the present edition in an incomplete form. Thus the poem Dudar (The Piper, see Vol. 2, p. 201) is printed here without the author's dedication 'Autaru "Białoruskaj historya" Vłastu' (To the author of the "Byelorussian History" Vłast) which preceded it when it was first published in 1910 in the newspaper $N a s ̌ a$ Niva, and later in the book Slacham žyćcia (1913). 'Vłast' is the pseudonym of Vacłaŭ Eastoŭski (1883-1938), the Byelorussian scholar and writer, author of the first history of Byelorussia ever printed in the native language, which appeared in 1910. The official attitude towards him and his works in present-day Byelorussia is one of hostility, hence the suppression of any mention of connections between him and Kupała. An example of omissions in works belonging to the second group (i.e. written in 1935-41) may be provided by the nowadays much-quoted and praised poem Bielaruskim partyzanam (To the Byelorussian Partisans, 1941; see Vol. 4 , p. 382), from which the following stanza has been omitted:

Vašy bitvy ŭvieś śviet bača,

Bača Stalin rodny naš,

Jak fašystaŭ rod sabačy,

Ludarezaŭ zbrod śmiardziačy

Niščyć vaša varta-straž.

Janka Kupała is considered today to be the greatest Byelorussian poet. For this reason alone it is of great importance both for the scholar and the general reader to have an authoritative edition of his complete works. This aim the editors of the present publication have failed to achieve. Moreover, with the help of all the trappings of a critical and scholarly approach, they have misled the reader, by presenting to him Kupała not as he really was, but as they want him to appear. It would have been more appropriate if they had called their edition selected and corrected works. As it stands, it must be used with circumspection.

\section{A. Nadson}

Padłužny, A. I. Narys akustyčnaj fanietyki biełaruskaj movy. 'Navuka i Technika', Minsk, 1977. 166 pages.

The title of the book 'AcousticPhonetic Study of Byelorussian' (an
'Essay on Acoustical Phonetics of Byelorussian' according to the author's 